\title{
Enhanced Contact Rights for Grandparents? A Critical View from Spanish and Catalan Laws
}

\author{
prof. dr. J. Ribot Igualada*
}

\section{Introduction}

This article ${ }^{1}$ examines how Spanish and Catalan ${ }^{2}$ laws deal with claims of grandparents who seek contact with their grandchildren against the will of one or both parents, and the scope given to their rights.

It starts by explaining the content and the goals of the legal reforms enacted at the beginning of the 21st century to promote grandparents' interests [Section 2]. Then, it presents the case law developed in the interpretation of the relevant legal rules [Section 3]. Finally, the situation of the law is critically assessed, taking into account the interests of all the parties involved (parents, grandparents, and grandchildren) [Section 4].

\section{The legislative path}

At the beginning of the twenty-first century, Spain - like many other European jurisdictions before ${ }^{3}$ - sought to improve the legal position of grandparents concerning contact with grandchildren through Act 42/2003, of 21 November. ${ }^{4}$ Cata-

* Jordi Ribot Igualada is Professor of Civil Law at the Institute of European and Comparative Law and Director of the Institute of European and Comparative Private Law (University of Girona).

1 The author is grateful to Marianne Holdgaard and Terje Stordalen for their support and to the participants at the Aalborg Second FamLaPP Annual Conference for their insightful comments and feedback on an earlier version of this article. The anonymous reviewer's guidance has also significantly improved it. Any mistakes remain my own.

2 Except for some limited exceptions, Catalonia is to be treated in family law as a jurisdiction in its own right. The Catalan Civil Code (hereafter CCCat) regulates substantive family legal issues in its second Book (enacted in 2010). The Superior Court of Justice of Catalonia hears appeals on family law as a last resort. Spanish and Catalan civil codes bear the same legal value in this paper's subject-matter.

3 For instance, France (1970), the Netherlands (1995) or Germany (1998). See the overview provided by G. Kovačec Stanić, 'Personal relationship between the child and his/her grandparents in comparative family law', in: H. Fulchiron (ed.), Les solidarités entre générations - Solidarities between generations, Brussels: Bruylant, 2013, p. 407-421, at 409 ff. See also Commission on European Family Law, Principles of European Family Law on Parental Responsibilities, Cambridge, Antwerpen: Intersentia, 2006, p. 167 -172. See also K. Boele-Woelki, B. Braat \& I. Curry-Sumner (eds.), Family Law in Action. Vol III, Parental Responsibilities, Cambridge, Antwerpen: Intersentia, 2005 at Q44, p. 577-594.

4 BOE n 280, 22.11.2003. 
lan Law anticipated this development when in 1998 the Family Code made specific reference to grandparents' contact rights. ${ }^{5}$

In fact, since 1981, a provision of the Spanish Civil Code (hereafter CC) already protected the personal relations between minor children and their relatives or close friends. ${ }^{6}$ However, the promoters of legal reforms said that this provision was only a 'residual reference' and that it did no justice to the grandparents' vital role in the life of grandchildren. ${ }^{7}$

A bill was introduced into parliament to give grandparents more visibility and to enhance their legal position, in particular in divorce proceedings. The first draft made contact with grandparents compulsory in any divorce or legal separation procedure involving minor children. Criticisms from numerous quarters - among them from the Fiscal General del Estado ${ }^{8}$ - forced the government to amend the bill. The main innovation and leitmotiv of the reform waned. The resulting Act 42/2003 only added the mention to 'grandparents' in the pertinent provisions of the Spanish civil code. Artikel 160 II CC stipulates that:

'Personal relationships between the child and his grandparents and other relatives and close friends may not be prevented without just cause. In the event of opposition, the Judge, at the request of the minor, his grandparents, relatives or close friends, shall decide, attending to the circumstances' ${ }^{9}$

The practical effect of Act 42/2003 was limited to make (theoretically) faster and simple tools available to enforce their claims. ${ }^{10}$

Despite the limited extent of the changes it introduced, Act 42/2003 has undoubtedly been quite effective in symbolic terms. It has given visibility and prominence to the interests of grandparents in conflict with their children about personal rela-

5 See Art. 135.2. An amended version of this provision is currently in force as Art. 236-4.2 CCCat.

6 Art.161 Spanish Civil Code (hereafter CC) (as amended by Act of 1981 on divorce): 'No podrán impedirse sin justa causa las relaciones entre el hijo y otros parientes y allegados' ['Personal relationships between the child and relatives and close friends may not be prevented without just cause'].

7 See also Preamble $\S$ V Act 42/2003. More references to the prelegislative stage and political initiatives towards legislative change in A.M. Colás Escandón, Relaciones familiares de los nietos con sus abuelos: derecho de visita, estancia, comunicación y atribución de la guarda y custodia, Cizur menor: Aranzadi 2005, p. 25-34.

8 The Fiscal General del Estado is the State Attorney responsible for the protection of children.

9 This article was amended in 2015 to include a specific mention to siblings. Legal scholarship tends to highlight that the legal reform was unnecessary since case law had long recognized contact rights to grandparents. Among others, see M. Carballo Fidalgo, "El "derecho de visita” de los abuelos y la atribución de la guarda de sus nietros tras la Ley 42/2003, de 21 de noviembre: aspectos sustantivos y procesales', Revista de derecho de familia 2006 vol. 30, p. 45-80, at 47-48. Some even point to the interests of the conservative government to appeal the aged electorate (J. Egea Fernàndez, 'Comentario a la Sentencia de 28 de junio de 2004', Cuadernos Civitas de Jurisprudencia Civil 2005 vol. 68, p. $747-764$, at 756 .

10 Grandparents were allowed to use the same legal procedure applicable to divorcing couples. On the hesitations that existed about the right procedure to use before the reform, see J.M. Rivera Álvarez, 'Reconocimiento judicial del derecho de visita de los abuelos a sus nietos y ejercicio de la patria potestad. Acceso casacional del problema de la extensión del régimen. La disposición transitoria $10^{a}$ de la Ley de 13 de mayo de 1981 (Comentario a la sentencia del Tribunal Supremo (Sala $1^{a}$ ) de 23 de noviembre de 1999)', Revista de derecho privado 2001 vol. 85, p. 75-87. 
tionships with their grandchildren. Besides, the preamble of Act 42/2003 provides a clear statement of the principles governing this area of law.

Firstly, the preamble emphasizes the unique role of grandparents in family life ${ }^{11}$ and that family goes well beyond parents and children and encompasses grandparents and other relatives. ${ }^{12}$ Compared with these relatives, however, grandparents must have a different and superior status because of their proximity and experience. ${ }^{13}$ The Supreme Court had already declared that grandparenthood is a 'privileged degree of kinship', and that the foundation of contact lies in that it gives grandchildren the chance to interact with persons other than the parents. 'The personality of the child' - the Court argued - 'is built by exposing him or her to the contradictions flowing from the grandparents' or other relatives' opinions. ${ }^{14}$ Along the same lines, the Superior Court of Justice of Catalonia, dealing with Catalan law, also highlighted that

'grandparents, in today's society, play an important role in socialising their grandchildren. Affective relations, blood bonds, conveying life experiences and the interest in the transmission of ideas and beliefs today, do constitute a personal and cultural heritage of undisputable value for those who are beginning their life journey'. ${ }^{15}$

On the other hand, Act 42/2003 starts from the assumption that grandparents should not be on equal footing with parents. ${ }^{16}$

The preamble also elaborates on the role of grandparents in connection with the break-up of the parents. It points to grandchildren's need for stability and remarks that grandparents might fulfil a reassuring role for children:

'[Grandparents] have a moral authority and can see the couple's problems with an impartial perspective; this may help grandchildren by rationalising the family conflict and contribute to their stability and development. [They can also] compensate hostility or confrontation between the parents with safe and necessary references that might neutralise the negative and traumatic effects of family break up. ${ }^{17}$

12 Preamble $\S$ V. On the legal relevance of personal bonds that go beyond parenthood, see E. Ryrsted, 'From the nuclear family to the legal acceptance of the "star" family: About the adults in the family', in this issue.

13 Preamble $\S$ VII.

14 Judgment of the Supreme Court (hereafter STS) 477/1996, 11.06.1996.

15 Judgment of the Superior Court of Catalonia (hereafter STSJC) 9/2001, 19.02.2001.

16 Some amendments proposed by left-wing opposition parties linked grandparents' contact rights with their personal and financial responsibilities vis-à-vis grandchildren. As a result, the proposals treated grandparents as joint holders of parental responsibilities, together with the parents, whose contact time with (grand)children they should share. These proposals were rejected. See BOCG, Congreso, VII Legislatura, Serie A, n. 168-6, 25.09.2003, p. 18-19.

17 Preamble § VII. 
It must be recalled, however, that the initial plan of involving grandparents in all custody arrangements, presumably to carry out this stabilization role, failed. Interestingly, the preamble also highlights that the new law

'[also] aims at setting out safeguards against other situations that might damage the relationship between grandchildren and their grandparents, like the parents' disinterest or the absence of any of them.'18

The legislator focused on divorce situations for enhancing grandparents' contact claims. However, the scope of the law is more wide-ranging. ${ }^{19}$ Grandparents can seek legal relief whenever they cannot visit with their grandchildren because of the opposition of one or both parents.

This is scarcely a novelty. All cases decided until then by the Supreme Court were conflicts arising from one of the parent's death. In none of them, the parents' divorce or separation caused the estrangement.

The latest reform of Catalan family law culminated the legislative evolution by transferring to specific legal provisions the predominant doctrinal view that the grandparents' claim was an individual right ${ }^{20}$ whose holders are both grandchildren and grandparents. ${ }^{21}$ Even though the claim stands as a reaction against the (unfair) exercise of the powers of the holders of parental authority, Catalan legislation chose to recognize it categorically as a right. This approach is consistent with the protection of the children's relational autonomy as an instrument for the free development of their personality. ${ }^{22}$ Moreover, the Catalan legislator wanted to give higher symbolic weight to the interests of grandparents and other relatives. Therefore, in addition to declaring that children have the right to keep relations with grandparents, siblings, relatives and close friends, Artikel 236-4.2 CCCat now states that 'all these persons also have the right to keep relations with them'. ${ }^{23}$

18 Preamble $\S$ XII. Emphasis added.

19 J. Egea Fernàndez, 'El dret a les relacions personals entre avis i néts. Notes per a una nova regulació en el dret civil de Catalunya', in: E. Amat i Llari \& J.M. Abril Campoy (eds.), Homenaje al professor Lluís Puig i Ferriol, vol. 1, València: Tirant lo blanch, 2006, p. 1213-1248 at 1236.

20 R. Gaya Sicilia, 'El derecho de los abuelos a relacionarse con sus nietos', Anuario de derecho civil 2002 vol. 55, p. 91-114 at 94-95. Art. 57 of Aragonese Act 13/2006, of 27 December, on the Law of the Person, also stipulated expressly that contact with their grandparents and other relatives was $a$ right of the children that parents and guardians could not prevent unless the interest of the minors required it.

21 S. Díaz Alabart, 'El derecho de relación personal entre el menor y sus parientes y allegados', Revista de derecho privado 2003 vol. 87, p. 345-371 at 355-356.

22 M. Rivera Álvarez, 'El derecho de los parientes y allegados a relacionarse con los menores de edad. Artículo $160.2^{\circ}$ y $3^{\circ}$ párrafos del código civil', Revista de derecho privado 2000 vol. 84, p. 635-672 at 644.

23 M. Anderson, 'Comentari de l'artikel 236-4', in: J. Egea Fernández \& J. Ferrer Riba (eds.), E. Farnós Amorós (ed.), Comentari al llibre segon del Codi civil de Catalunya. Família i relacions convivencials d'ajuda mútua, Barcelona: Atelier, 2014, p. 805-812 at 811. 


\section{The judicial developments}

\subsection{The autonomy of grandparents' contact rights}

One of the aims of the reform was to underpin the autonomous character of the rights of grandparents. The reformers emphasized the need to solve situations in which the personal relations with one's grandchildren were made dependent on the custody or contact arrangements between the parents after their break-up. Courts have held that the autonomy of grandparents' contact rights entails that they can claim their own time with grandchildren regardless of the arrangements made by the parents. They do not need to sue both parents either, provided that only one of them exercises de facto the parental responsibilities. ${ }^{24}$

\subsection{Grandparents' contact rights do not require a prior close relationship}

Many of the contact cases that reach the justice system involve grandparents who have enjoyed a close relationship with their grandchildren. The relevant statutory provisions, however, do not clarify whether the personal relations protected by the law must have existed before filing the claim or not. ${ }^{25}$

In the view taken by the courts, a prior close relationship with grandparents is by no means a legal requirement to file a claim or to contact with the grandchildren. Since its first decisions on this matter, the Supreme Court awarded contact rights to grandparents who had never met their grandchildren or who barely knew them. ${ }^{26}$ By doing so, the courts recognize the interest of grandparents in relationship-building and give them the chance to develop their role as grandparents despite the opposition of the parent(s). The Supreme Court pointed out that 'grandparents [have a] legal right to have close personal contact with the person whom they have a link of kinship that justifies a special affection.'27

This standpoint contrasts with the treatment given by courts to other relatives and close friends. ${ }^{28}$ In the case of an aunt who had never met her niece, the Supreme Court ${ }^{29}$ rejected the action because it 'did not seek to restore an interrupted relation,

26 STS 477/1996, 11.06.1996 granted paternal grandparents contact time with a grandchild to whom they did not know because the father's death happened when the child was very young. STS 17.09.1996 confirmed the appellate court decision granting contact to the grandfather, even though he had lost contact with his one-year-old grandchild after he had accused the father of killing his daughter. The Court stressed the need to reinforce family bonds regardless of the reasons that led to the current hostility between father and grandfather.

27 STS 576/2009, 27.07.2009. The principle underlying this statement is that it is the blood relationship that should lead to special affection and from there to the opportunity of contact. In the case at stake, however, a close personal relationship could have existed between the grandparents and the grandchild. The grandchild was four years old when proceedings started. His mother had died and her death led to the estrangement between the father and the maternal family.

28 From the very beginning, legal writing recalled that the rule on contact with relatives and close friends replicated the French reforms of 1970s. Accordingly, the prevailing view among Spanish legal writing is also that grandparents shall be treated better than other relatives, regardless of the general character of Art. 160 CC.

29 STS 516/2015, 16.09.2015. 
but to create one anew' ${ }^{30}$ The child's father and his sister broke off relations many years before, on the occasion of the former's marriage against the opinion of their late parents. He had moved from his home region to start a new life with his spouse, free from family interferences, at the other end of Spain. Interpreting Artikel 2364.2 CCCat, the Superior Court of Justice of Catalonia also held the view that, in contrast to grandparents, other relatives and close friends must provide evidence that a unique link already existed with the children at the time of estrangement. That was indeed the case: the claimant was an aunt who had cared for a disabled nephew during the first years of his life; she was abruptly separated from him when the relationship with her sister, the child's mother, deteriorated. ${ }^{31}$

\subsection{Personal relations with grandparents are presumed to be good for grandchildren}

The prevailing opinion is that grandparents' influence is good for grandchildren. Accordingly, courts consider that granting contact with them is going to have a positive effect on the construction of children's personality and the meeting of their needs.

Following the lines set out in the preamble of Act 42/2003, courts devote a substantial part of their decisions to repeat the idea that the relations between grandparents and grandchildren are worth preserving and should be encouraged. Courts recall the 'ever enriching character of the relationship between grandparents and grandchildren', ${ }^{32}$ and that contact with extended paternal family is essential as a factor of stabilizing the children and as an enriching experience. ${ }^{33}$ The claimants in actions brought under Articles 160 CC or 236-4.2 CCCat must prove that they are the grandparents of the children and that the parents refuse to let them engage in a significant family relationship with them. It is for the parents to justify why they do not adhere to the social practice that children have a meaningful relationship with their grandparents.

\subsection{Only full evidence of justified grounds - 'justa causa' - allows rejecting contact}

According to Articles 160 II CC and 236-4.2 CCCat, parents are prohibited from preventing personal relationships of children with their grandparents unless there are grounds legally justifying them to do so (justa causa).

Since grandparents' relations are beneficial per se, the burden of proof lies with the parents objecting contact. ${ }^{34}$ In practice, all proceedings involving conflicts between the parent(s) and grandparents end by discussing whether the allegations of the former are substantiated. In general, case law tends to conflate this analysis with the assessment of the best interest of the children.

As in custody proceedings, a great deal of importance is given to evidence provided by psychologists and other professionals reporting before and during the trial. In practice, most rulings are based on these reports, primarily when issued by the social intervention teams belonging to the family courts. These experts provide 
independent advice to the judges. Because of the impartiality of their report, a grandmother who had accused the father of sexually abusing her granddaughters succeeded in obtaining supervised contact. The social intervention team examined the grandchildren and the grandmother and recommended restoring their relation, notwithstanding the adverse effects that the criminal prosecution had caused to the whole family. ${ }^{35}$ On the other hand, it is not unusual that expert evidence alerts about the psychological risks of awarding contact if tensions between parents and grandparents have not been scaled down. Case law, however, regularly dismisses such an approach and demands evidence of an increased likelihood of severe psychological harm to deny contact or to limit its scope. ${ }^{36}$

In practice, the Courts do not give much weight to the opinion of grandchildren. ${ }^{37}$ They consider that grandchildren may find themselves in a loyalty conflict and be reluctant to deliver testimony. Their opinion about not having contact with grandparents is often disregarded as being manipulated by parents, or not freely given. ${ }^{38}$ However, the age and maturity of the children should be very relevant. ${ }^{39}$ The law requires to hear children over the age of twelve, and it also recommends to do so if younger children are mature enough. ${ }^{40}$ The Supreme Court has indeed taken the stand to insist that mature children must be provided with the opportunity to be heard before confirming the scope of their grandparents' rights. ${ }^{41}$

\subsubsection{Grounds that do not justify denying contact}

- Bad relations between parents and grandparents

Bad relations between the parent(s) and the grandparents are taken for granted in these cases. In the absence of conflict, the parties would not have undergone the nuisance of court proceedings. Refusing to award contact with grandchildren because the parties are not on good terms would short-circuit a protected legal interest of the grandparents. As the Supreme Court once put it, 'it would be enough that [father] continues to detest his in-laws, so that they could not ever communicate with their granddaughters' ${ }^{42}$

The seriousness of the causes underlying the animosity between the parties is irrelevant. Accordingly, a mother assaulted by her husband cannot oppose that her

37 STS 632/2004, 28.06.2004 ('it is not possible to identify what they expressed with their interest').

38 SAP Jaén, Section $1^{\text {st }}, 595 / 2000,30.11 .2000$ said that the child's refusal must be worked out together by the mother and the grandparents; it does not justify the separation.

39 Older grandchildren's opinions are given greater importance. For instance, a 16-year-old grandson cannot be compelled to visit his grandparents (SAP Las Palmas, Section $3^{\text {rd }}, 323 / 2018,24.05 .2018$ ).

40 Cf. Art. 9 Organic Act 1/1996, of 15 January, on the legal protection of minors. See also art. 770.4 in fine Civil Procedure Act.

41 On occasions, Courts have stressed that children must be heard about the contact arrangements with their grandparents. In some instances, the case has been remanded to the instant Court (STS $477 / 1996,11.06 .1996,632 / 2004,28.06 .2004$ or 18/2018, 15.01.2018). On the importance of the child's own views to define their best interest from the standpoint of Art. 8 ECHR, see K. Sandberg, 'Grandparents' right to contact with their grandchildren under the European Convention on Human Rights (ECHR)', in this issue. 
mother-in-law keeps in contact with grandchildren, even after the latter had supported the man during the criminal proceedings. ${ }^{43}$ The parents cannot refuse the maternal grandmother from visiting their daughters despite her having erroneously accused the father of sexually abusing them. ${ }^{44}$

In the case finally decided by the ruling of the Supreme Court 689/2011, 20 October 2011, the trial Court had argued that the father suffered severe psychological problems each time he met his mother, and rejected her claim to have contact with a granddaughter. The parents had decided to protect their children from the mental health troubles that his mother had caused the father. The Supreme Court nonetheless quashed the decisions of the lower courts, granted claimant's contact with both granddaughters, and said that the reasons adduced by the father were negligible. The Supreme Court rebuked the trial Court's judgment because it had based it 'not on the best interest of the child, but the interest of the father' ${ }^{45}$

\section{- Risk of psychological damage}

Sufficient reasons to prevent grandparents' contact do not include the mere risk of psychological damage resulting from manipulation or bad influence by grandparents during contact time. Courts tend to dismiss these allegations as speculative. ${ }^{46}$ The defendants must prove an increased likelihood of psychological harm with specific examples showing that contact with the claimants already resulted in damage to the children. ${ }^{47}$

If the conduct of the claimants before and during the procedure makes it very likely that they might misbehave, courts may still grant contact, albeit limited or conditioned. In these cases, courts usually add admonishing paragraphs to the judgments ${ }^{48}$ in which they remind the claimants that they must avoid criticisms of the parent(s) or tryto manipulate or distort the children's opinions about their family. ${ }^{49}$ In one case, for instance, the father complained that the extended maternal family had been publicly saying that he had caused his wife's death. He feared that his daughters would be told this when they were to visit their grandparents. The Supreme Court granted the requested contact, although it deemed the parent's fear

SAP Barcelona, Section $18^{\text {th }}, 507 / 2012,19.07 .2012$.

STS 551/2016, 20.09.2016.

A critical comment on this decision, by C. Guilarte Martín-Calero, 'El derecho de los nietos a mantener relaciones personales con sus abuelos (a propósito de la sentencia del Tribunal Supremo de 20 de octubre de 2011)', Revista de derecho de familia 2012 vol. 56, p. 45-60.

STS 689/2011, 20.10.2011 (psychological risk linked to the conflict between father and grandmother could affect the children but only 'indirectly and hypothetically'.) Along these lines, STSJC 24/2014, 07.04.2014 declared that a mother could not prevent contact invoking the 'mere speculative idea' that the daughters could be psychologically harmed by the hostility that grandparents show against her. The Provincial Court of Barcelona had rejected granting any contact order to the grandparents on the basis of the welfare of the children. It pointed to the fact that the children did not know their grandparents, had no relationship neither with them nor with their father, and that the conflictive relationship between the mother and paternal grandparents had escalated, including several crossed actions in both civil and criminal courts.

47 STS 359/2013, 24.05.2013 upheld the appeal against the judgment that had refused contact on the basis that 'the legal ground to deny the relationship is declared in a purely speculative manner since no concrete episode [of damage to the child] is proven'.

48 SAP Madrid, Section 22 ${ }^{\text {nd }}, 80 / 2019,29.01 .2019$.

49 See for instance SAP Asturias, Section $1^{\text {st }}, 215 / 2019,21.03 .2019$. 
reasonable. Therefore, it warned the claimants that the Court could immediately suspend or annul the visits if they violated the prohibition of blaming the father for the mother's death. ${ }^{50}$

\subsubsection{Grounds that justified denying contact}

- Instrumental use of contact actions

Two Supreme Court decisions provide illustrations of this type of situation, which has exceptionally led to dismiss the grandparents' claim. In the first case ${ }^{51}$ the Court concluded that the petition of the grandmother was not in the best interest of the child. The grandmother - contact only to keep her conflict with the parents alive; she had never conveyed any interest in the child since her birth, seven years before she filed her action. In the second case, the Supreme Court criticized the claimants because they had not assumed their role as grandparents. ${ }^{52}$ Between the lines, one may read that they tried to impose their views on their son. They had reacted aggressively when he relocated and started living apart with his own family. The grandparents used the action to harass their son and to punish him for having disobeyed them. ${ }^{53}$

- Likely risk of serious psychological damage

The few decisions that reject granting contact to grandparents rely upon the fact that, under the circumstances of the case, there is an increased likelihood that grandchildren might suffer severe psychological damage if contact is enforced. The potential damage is connected with the possibility that grandchildren are trapped in a loyalty conflict because grandparents are not prepared to set aside their ill feelings towards the parent(s).

Two recent Supreme Court rulings address this scenario.

In the case dealt with by the first judgment, the paternal grandparents filed a lawsuit seeking contact with their two grandsons, who were then four and seven years old. The first instance court carried out an exhaustive evidentiary activity to verify the likely impact of establishing contact with the paternal family. The father was being prosecuted under the accusation of having sexually abused his children. Despite several reports pointing to the risk that the evocation of the father figure through contact with the grandparents could cause a regression in the treatment received by the children, the trial judge granted supervised and strictly limited contact at a family meeting point. The Provincial Court upheld the mother's appeal and dismissed the claim in its entirety. The grandparents appealed in cassation. The Supreme Court emphasized, first, that the law does not define the legal ground mentioned by Artikel 160 II CC and 'that it must be assessed on a case-by-case basis under the guidance of the best interests of the child'. After such a generic statement, the ratio decidendi is to be found in that a real risk existed, 'which is not

50 STS 858/2002, 20.09.2002. Other examples may be found in STS 689/2011, 20.10.2011

51 STS 167/2015, 18.03.2015.

52 STS 532/2018, 27.09.2018.

53 This is evident when the court points to 'the limited interest [of the claimants] to keep the relationship with their granddaughter leaving aside the conflict with her parents'. 
simply a lack of understanding between the grandparents and the parent'. The Provincial Court held that grandparents were suffering a loyalty conflict. Thus, there was a high probability of manipulation of their grandchildren 'causing the children to relive a painful situation, which has already altered their emotional condition and that has required follow-up therapy to overcome the problem'. ${ }^{54}$

The second ruling, already referred to earlier on, also exemplifies the exceptionality of the hypothesis of rejecting contact to grandparents. The Court emphasized that this case was very different from prior cases in which it had dismissed the parents' appeal because the likelihood of the damage was not substantiated. In the case at issue, on the contrary, 'the risk could not be considered merely speculative or theoretical but actual and serious'. ${ }^{55}$

\subsection{Scope of grandparents' contact rights}

Sometimes grandparents argue that they should have contact rights 'like a separated parent'. ${ }^{56}$ Case law, however, has watered down these expectations.

Firstly, the courts emphasize that the legal roles of parents and grandparents are very different. The privileged position of grandparents ${ }^{57}$ does not mean that they are on equal footing with parents. As a rule, the latter are the joint holders of parental responsibilities. Grandparents only fulfil a supportive role, in which they must be careful not to interfere with parental responsibilities. Besides that, even if the legal concept of 'personal relationships' is construed quite broadly, encompassing not only communications and meetings but also overnight stays, ${ }^{58}$ Courts start from the assumption that the scope of the rights awarded to non-custodial parents must be broader. ${ }^{59}$

54 STS 90/2015, 20.02.2015.

55 STS 532/2018, 27.09.2018. Compare with the admissibility decision 29.05.2019 (which held as irrelevant the risk posed by minimal supervised contact).

56 See the claims brought about by the participants in the press report elaborated by Pere Ríos, «iTengo derecho a ver a mi nieto!», published in El País 08.08.2008 (p. 28).

57 STS 632/2004, 28.06.2004 stressed that 'grandparents hold a special position with regard to their grandchildren', thereby establishing the grounds for widening the scope of contact as compared with the interests of other relatives or close friends.

58 STS 632/2004, 28.06.2004 held that the expression 'personal relations' could not be reduced to simple interactions during brief periods of time, but can consist of overnight stays, including stays for some days at the grandparents' home. At any rate, the Court eventually denied overnight stays of a 14-month-old grandchild and stayed proceedings with regard to the other grandson, then old enough to express his views. More recently, however, the Supreme Court clarified that overnight stays cannot be awarded in any case, in the same way as they cannot be ruled out without proper examination of all the circumstances (STS 723/2013, 14.11.2013). 
The Supreme Court ${ }^{60}$ tried to make a distinction between, on the one hand, the visitation rights of non-custodial parents and, on the other hand, the protected personal relationships with grandparents and close friends. Regarding the scope of these protected personal relations, the Supreme Court produced a list of relevant and not-exhaustive factors: 1 ) the particular situation of the child and the person seeking contact; 2) the conclusions of expert evidence; 3 ) the intensity of the prior relationship between the parties; 4) the need to respect the relationship of the child with the holder of parental responsibilities; 5) any other circumstance convenient for the child.

On occasion, courts quote this list. However, more often than not, the decisions are not very explicit about the factors that they have pondered. The grounds of judicial orders are frequently vague and rely on the appropriateness of the arrangement under the circumstances of the case. It is impossible to classify the decisions according to factual elements such as the intensity or duration of a prior relationship, the age of the children or the type of families involved, the age of grandparents or any other relevant circumstance. In many cases, courts do not even report these elements in their decisions.

The arrangements can be classified along a continuum. The provisions allowing overnight stays every month and in holiday time have the broadest scope. The minimum consists of temporary supervised meetings in supervised family meeting points (puntos de encuentro familiar). Between these two poles, most claims succeed in obtaining an order granting contact some hours per week, generally at the grandparents' home or in public places, with or without the parents. Courts also give great importance to meetings with grandparents on special days like Christmas, 'Reyes', ${ }^{61}$ birthdays and relevant family days. In practice, Courts are keen to order broader contact time in cases of death of one of the parents. These arrangements seem to be more frequent for maternal grandparents ${ }^{62}$ than for paternal grandparents. ${ }^{63}$ An implicit bias favouring the matrilineal family, based on the central role of the mothers in the raising of children, could exist. Some exceptions may, or may not, confirm this intuition. ${ }^{64}$

60 STS 320/2011, 12.05.2011. The case concerned a lesbian couple in which the biological mother complained that the instant Court had arranged excessive visitation rights for her former partner. In spite of criticizing the conceptual confusion of visitation rights and protected personal relationships, the ruling confirmed the scope set out by the court. Accordingly, the child would spend half of the weekends and the holidays with his stepmother, and she could contact him some time during the week. The case did not end there: STS 15.01.2014 decided that the relevant conduct of both parties before and after the childbirth (cohabitation with the child as mother, conclusive acts of both parties regarding the ART that were undertaken jointly) led to the conclusion that it was in the best interest of the child that the claimant obtained the legal status of (second) mother.

616 January is the day on which young children receive family gifts.

62 See for instance STS 858/2002, 20.09.2002. See also SAP Almería, Section $1^{\text {st }}, 144 / 2018,06.03 .2018$. In STS 18/2018, 15.01.2018 the grandmother appealed because after having cared for the child for four and a half years after birth, she was not satisfied with the minimal contact granted after her daughter's death. Since the grandchildren grew up during proceedings, the court finally remanded the case to the instant court to hear the opinion of the minor, then 14 years old.

63 STS 632/2004, 28.06.2004: one weekend with overnight stay per month; grandparents had asked for sharing weekends and holidays. See also STS 576/2009, 27.07.2009.

64 However, STS 723/2013, 14.11. 2013 confirmed a broader contact regime for paternal grandparents. 
On the other hand, the more contentious cases end with orders awarding minimal contact time. Very often, Courts set up specific protective safeguards and increasing contact time is possible depending on the evolution of the relationship. ${ }^{65}$ The reporting of specialized staff about how the contact develops often determines whether it should be continued or discontinued. On occasions, however, contact may be strictly limited, irrespective of the evolution of the relationship between grandparents and grandchildren.

\section{Discussion}

The analysis of Spanish and Catalan laws on grandparents' statutory contact rights and of the judicial developments about their interpretation and application allows drawing some critical conclusions.

The bottom line of this section is that continuing to provide privileged treatment to grandparents is unfeasible from the standpoint of the best interests of the children. The prevailing approach of courts and legal writing is therefore critically assessed because it undermines the impartiality of the legal system when it comes to decide whether and to what extent contact can be coercively imposed. ${ }^{66}$

A number of relevant legal actors seem to have realized that the way of addressing the issue of grandparents' contact may have allowed unmeritorious applications. The most recent decisions of the Supreme Court have broken through a trend to put greater emphasis on the need to subject the grandparents' claims to the examination of what is the real benefit of the requested contact for the children involved. ${ }^{67}$

\subsection{Grandparenthood, relatedness and the presumption of welfare}

Spanish Courts do not require grandparents claiming contact to have had a prior close relationship with their grandchildren. ${ }^{68}$ Courts also apply the legal presump-

65 SAP Barcelona, Section $18^{\text {th }}, 503 / 2016,20.06 .2016$ (order granting supervised contact to be confirmed or not according with the report of the social intervention team).

66 Aragonese legislation already replaced the reference to justa causa with the assessment of the best interest of the children (Art. 60 II CDFA). Art. 236-5.1 CCCat also assumes that damage to the children's interest justifies the contact's suspension or denial. In neither case, however, does it need to be concluded that the relationship with the grandparents must be convenient for the minors, but only that their interest may justify dismissing the grandparents' claim.

67 Concerning the position of the ECtHR, F. Swennen claims that it seems 'almost to amount to a presumption in favour of near relatives that parents would have to rebut' ('Personal relations and contact concerning children', in: B. Stark and J. Heaton (eds.), Routledge Handbook of International Family Law (Abingdon, Oxon [UK]; New York, NY: Routledge, 2019) p. 161-174, at 166). But see K. Sandberg, 'Grandparents' right to contact with their grandchildren under the European Convention on Human Rights (ECHR)', in this issue.

68 See for instance SAP Jaén, Section 1 $1^{\text {st }}, 221 / 2019,05.03 .2019$ : in this case the mother was abandoned at an early age and she did not have any relationship with her mother until she sued her to be granted contact with her 4-year-old grandson. The Court dismissed the claim, but not for lack of prior close relationship with the child. It contended that enforcing any right of contact would inevitably worsen the disability of the child. On the contrary, SAP Madrid, Section 22 ${ }^{\text {nd }}, 516 / 2018$, 12.06.2018, dismissed the claim arguing that the lack of relationship between grandparents and grandchildren was 'absolute'. 
tion that contact with grandparents has to be granted unless the defendants provide justified grounds. ${ }^{69}$ Evidence of justified grounds for denying contact is required in all cases, not only when a relation existed before the claim, or at some point at least, or with some level of intensity. Accordingly, grandparents' statutory contact rights exist automatically as a function of blood ties. Mere relatedness leads to significant substantive and procedural consequences: grandparenthood allows presuming the existence of affection (actual or to be developed naturally) and that contact is appropriate.

Many authors emphasize that any decision must consider the best interest of the child. ${ }^{70}$ Case law also insists upon connecting the justa causa mentioned by Articles 160 II CC and 236-4.2 CCCat with the assessment of the best interest of the child. However, under the current legal framework, based on a strong presumption that contact with grandparents is always good for children, the essential question of the welfare of the particular child seems to be detracted. ${ }^{71}$ Too often, general untested assertions substitute the contextual analysis of the case. Judgments issued in this area of law typically lack a thorough examination of the relevant elements that justify grandparents' contact and that explain its scope. As Torres Perea put it, there is a tendency to cover up under the welfare of the child 'the sheer imposition of a certain natural order based on biological data and relatedness, as if it would be an unavoidable demand of our cultural tradition, for the benefit of the grandparents only, and regardless of the impact on the child's interest'. ${ }^{72}$

When deciding on grandparents' contact, courts are not required to undertake a critical assessment of the claimants' attitudes and aptitudes vis-à-vis their grandchildren. Courts do not usually base their decisions on evidence about their fitness or experience whatsoever. Topical stereotypical images of grandparenthood are regularly used to support the presumption that contact is pertinent in the case at stake. The considerations set out in the statute's foundations are not assessed in concreto, according to the circumstances of the case. The role of stabilization, as well as other functions statutorily predicated of grandparents, are not assigned to the claimants after considering their age, capacity or economic standing. Courts do apply the statutory framework on the assumption that they have the qualities stated in general for grandparents, namely that they are devoted and caring persons or

69 Art. 160 Spanish Civil Code = Art. 236-4.2 Catalan Civil Code.

70 Legal writing stresses that any decision that affects a minor must be based on his or her best interest, which includes the decision on the personal relationships that his or her grandparents want to establish (Guilarte Martín-Calero, 2012, p. 49-50). However, as Salanova Villanueva put it, 'the direct bond that links them allows the presumption that personal contact is going to be beneficial for the minor, and this gives the grandparents a "title" by reason of which they can rightfully claim contact' (M. Salanova Villanueva, 'Notas sobre el derecho de los abuelos a mantener relaciones personales con sus nietos (A propósito de la Sentencia de la Sala Primera del Tribunal Supremo de 7 de abril de 1994)', Anuario de derecho civil 1996 vol. 49, p. 943-976, at 960-961). In other words: 'The foundation of this right is no other than the interest of the grandchildren; that is, the fact that contact with their second degree direct line relatives will benefit them in their affective, personal, psychological and intellectual development' (Colás Escandón, 2005, p. 51).

71 See also J. M. de Torres Perea, 'El artículo 160.2 y 3 del código civil, norma reguladora de un conflicto de intereses entre padres y abuelos', Diario La Ley 2001 no. 5296, p. 1-4

72 Torres Perea, p. 3. 
that they will undoubtedly be so. ${ }^{73}$ They are also presumed to be able to perform the roles legally and socially assigned to grandparents and to do so by spending time with grandchildren, expecting no, or very little, cooperation from the parent(s).

A recent case provides a perfect illustration for this approach. ${ }^{74}$ The Court acknowledged that the origin of the problem was 'the obvious dominant attitude of the grandparents, who reject the existence of family troubles and do not assume their share of responsibility in the conflict'. Still, it concluded that

'The disagreement between the parents and the appellants ... shall not lead to the dismissal of the claim, since no additional elements are preventing the relationship between the grandparents and the grandson; they have always welcomed him and treated him as they understood best. [...] despite the lack of relationships between the parties, the best interest of the child implies that visiting his grandparents is good for the boy, insofar as one can presume that contact with members of the extended family is positive for his development; accordingly, an attempt to normalise the relations must be made, or at least an attempt to approach the parties and resume the contact'.

Courts disregard the particular personal features of the claimants, both in terms of their past personal history or behaviour, or their current abilities to interact with young children. It is striking to see that courts tackle these concerns in cases where two lines of grandparents are quarrelling over custody. ${ }^{75}$ Moreover, on occasion, the Constitutional Court has rightly quashed judicial decisions that have ordered contact time to grandparents without giving substantial reasons to explain the scope of the grandparents' rights in the case at stake. ${ }^{76}$ But this is also the case of decisions awarding contact. Many cases end by concluding that contact is in the best interest of the child, without engaging in a minimal analysis of the elements that colour the case.

73 To be sure, this analysis is in practice delegated to the in-court services that provide psychosocial reports on the litigated cases. Recent empirical research shows, however, that these reports tend to reccommend contact using a rather grandparent-centred and optimistic stance, provided that the claimants conform to the stereotypical role. See M. Celdrán, F. Villar and E. Benito, 'Grandparent Visitation Rights in Spain: Which Psychosocial Arguments are Taken into Account to Grant or Deny Visits?', Psychiatry, Psychology and Law, 2018, 25(1), p. 59-71, at 68.

74 SAP Asturias, Section $7^{\text {th }}, 392 / 2012,24.07 .2012$.

75 One could mention STS 47/2015, 13.02.2015. In this case the mother was convicted for the premeditated assassination of her former partner and father of her child. The child remained under the custody of a paternal aunt after the crime. The maternal grandparents were awarded contact time with their grandchild, but the underlying animosity between families made these fail. They responded by asking for a change in custody arrangement and on appeal the Provincial Court granted custody to them as a response to the failure of previous contact arrangements. The Supreme Court quashed this decision, which was qualified as disproportionate and lacking justification.

76 Constitutional Court, $2^{\text {nd }}$ Chamber, 138/2014, 8.9.2014: a father filed an appeal for protection of fundamental rights before the Constitutional Court against the order granting broad contact rights to maternal grandparents after the mother's death. The Constitutional Court upheld the appeal and quashed the decision because the lack of a meaningful reasoning justifying the scope of grandparents' contact rights entailed a violation of the father's fundamental right to judicial protection (Art. 24 Spanish Constitution 1978). 
The parent's traumatic experience as children, for instance, is taken into account only exceptionally. ${ }^{77}$ However, it is very likely to have caused severe psychological effects. Without overcoming this trauma, it seems contentious to achieve something positive by forcing contact between grandchildren and grandparents. The non-existence of relations comes from the previous generation. A recent decision of the Provincial Court of Barcelona ${ }^{78}$ highlights this factor. The lawsuit concerned a paternal grandmother who neglected her children. During childhood, they got by with the support of another woman, who they henceforth took as their mother. The Court examined the context carefully, with witness and expert evidence, and concluded that 'the issue is whether contact is appropriate between an absent grandmother and a five-year-old granddaughter... while the primary vital relationship with her son is severely damaged, and she shows no desire to restore it'. The Court reproached the claimant that

'The reasons she alleges ... for wanting to visit the minor are not based on the expression of an affectionate feeling or an instinctive and natural emotion, but are purely biological, claiming that as daughters of his son she must get to know them.'

\section{To which the Court answered that}

'Before trying to impose a personal relationship between the grandmother and the granddaughter, the maternal-filial relationship must be restored... This Court urges once again the parties to try to understand the position of the other, to assume a reality that can no longer be modified and try to overcome painful memories to attempt an approach that will always be beneficial, not only for the girl but especially for the mother and the son. Once this approach is achieved, the relationship with the granddaughters will emerge naturally'. ${ }^{79}$

The Superior Court of Justice of Catalonia confirmed this judgment. ${ }^{80}$ It also criticized the claimant for acting based 'on purely biological reasons, and for arguing that "... they are daughters of her son ..." as if this gave her an unconditional right

77 On occasions, however, Provincial Courts have given more weight to parents' concerns as regards the capacity of grandparents to live up to the stereotypical role model. SAP Cádiz, Section $5^{\text {th }}$, $503 / 2013,14.10 .2013$, dealt with a case where the father and his siblings had suffered severe mistreatment at the hands of the claimant during their infancy. When he became of age, the defendant decided to break off relations and the Court upheld the decision he took with his wife to avoid exposing their children to his mother's violent character and negative, outdated values. See a similar case in SAP Barcelona, Section $18^{\text {th }}$, 39/2005, 02.02.2005. More recently, SAP La Rioja $70 / 2018,23.02 .2018$ argued that serious emotional harm might ensue for the son of the defendants in the case that contact time was awarded to paternal grandparents. Evidence about how they behaved as parents was crucial.

78 SAP Barcelona, Section $18^{\text {th }}, 179 / 2019,27.02 .2019$.

79 A very similar case, with the same results, has been dealt with by SAP Barcelona, Section $18^{\text {th }}$, 574/2019, 18.09.2019.

80 STSJC 63/2019, 23.10.2019. 
to be able to maintain, at present, a relationship that should be based on affective and caring pillars not proven in the case' ${ }^{81}$

Finally, legislation, case law and doctrine emphasize the 'bilateral' or 'reciprocal' character of contact rights. ${ }^{82}$ However, it is doubtful that the child can enforce his or her 'right' against unwilling grandparents. ${ }^{83}$ There are clear normative arguments to hold that grandparents' consent is critical. ${ }^{84}$ Besides that, such a legal framework gives rise to bizarre cases. In one that made headlines, the parents of a four-year-old child sued her grandmother, a 93-year-old woman who was living in a nursing home. For unspecified reasons, she was estranged from her daughter. Acting as legal representatives of the child, the parents - a judicial order compelling the woman to receive her granddaughter for two hours every Thursday. The grandmother successfully contended that although she loved her granddaughter very much, she wished not to meet her at the nursing home and that her present health condition prevented her from doing so. ${ }^{85}$ At any rate, the very personal nature of the right to contact suggests that its exercise by legal representatives is not feasible. Indeed, classifying that interest as a subjective right seeks that, when the conditions of age and maturity are met, the minor can directly claim if their parents do not facilitate the relations with grandparents. ${ }^{86}$

\subsection{Avoiding harm, doing good or simply hoping that nothing bad happens?}

The enhanced statutory protection of grandparents also obscures the standard to be applied to ascertain what is the best interest of the child. Judicial practice and settled case law seem to point to the idea that it is for the parents to provide evidence that reveals that contact time with grandparents will harm their children. Allegations of its potential negative psychological impact or other emotional instability side-effects are usually dismissed as speculative. Even when these complaints are considered reasonable, however, courts do still grant contact. Little likelihood of severe risk does not trump grandparents' rights. Only an increased probability of severe damage has allowed the rejection of the claim. Where the relationship is unlikely to produce neither harm nor good, contact time is awarded because it is positive and enriching per se. ${ }^{87}$

The analysis of the best interest should focus on (a) avoiding the harm that children are suffering due to them being separated from grandparents, or on (b) the

81 The deference to biological data and its sociocultural significance is highlighted nonetheless by the fact that all courts involved in this procedure recommended the parties to engage in family mediation to overcome their conflict.

82 See Rivera Álvarez, 2000, p. 644-645.

83 Guilarte Martín-Calero, 2012, p. 53.

84 See Art 90.2 and 94 CC (requiring consent to any contact order agreed upon in matrimonial proceedings). A.M. Colás Escandón, 'Consecuencias derivadas del incumplimiento del régimen de relaciones personales entre abuelos y nietos. Especial referencia al resarcimiento de los daños morales', Aranzadi Civil-Mercantil 2011 vol. 6(1), p. 111-142 at 117-118. SAP Balearic Islands, Section $4^{\text {th }}, 395 / 2018,10.12 .2018$.

86 See J. Ferrer Riba, 'Comentari a l’artikel 135 Codi de Família', in: J. Ferrer Riba \& J. Egea Fernàndez, A. Lamarca, C. Ruisánchez (eds.), Comentaris al Codi de Família, a la Llei d'Unions estables de parella i a la Llei de Situacions convivencials d'ajuda mútua, Madrid: Tecnos, 2000, p. 625-634 at 629. 
actual benefits that they will obtain from contact. However, litigated cases concentrate on the likelihood of harm arising from contact with grandparents only.

\subsection{Open-ended statutory rules}

Conflicts between grandparents and parents regarding contact with grandchildren usually arise in very different settings. The relevant statutory provisions and the practice of courts do not distinguish between the cases depending on the type of scenario in which parents challenge grandparents' claims. The same general principles apply when the family is disrupted by the sudden death of one of the parents, or by the divorce or break up of the couple, or when it is an intact family.

The different context seems to have no relevance when deciding the cases. However, the diverse background should also make a difference because the essence of the best interest test is to take into account the specific circumstances of the child and the family. The weight of each interest changes with the factual scenario. The fact that both parents are alive or not, or that they live a life separated from their children or with strong links with them, or that they have jointly decided to limit contact with the extended family, must influence the process of decision-making. Currently, however, the law does not apportion the burden of proving the elements that may be relevant for the decision. It shifts it all on the parents who decline grandparents' contact.

\subsubsection{Divorce or break-up of the parents}

If the problems started with the divorce or break up of the parents, it would be wise to know and assess whether it followed incidents of abuse or violence, or whether the grandparents' claim is instrumental in keeping conflict between parents alive. Act 42/2003 already introduced a caveat in divorce and separation cases: contact with grandchildren should not interfere with orders restricting parental time with children. ${ }^{88}$ Beyond that minimum, courts have secured the autonomy of grandparents' action. However, the children's time is nonetheless finite. After the separation of the parents, Courts should accommodate all potential contact claims to the arrangements approved during divorce proceedings. The Supreme Court ${ }^{89}$ recently quashed a decision that had granted contact rights to paternal grandparents in a petition filed jointly against the mother and the father, the latter eventually relinquishing to the action. The Supreme Court upheld the mother's appeal because the instant Court had not explained why the grandparents needed contact time while the father of the children enjoyed broad visitation rights and did not oppose that they visit their grandchildren.

Some scholars highlight the secondary character of grandparents' claims in cases of separation of the parents. Firstly, in many of these situations 'the intensity of these orders. Accordingly, courts deny grandparents' contact altogether, or award it only under special safeguards aimed at preventing them from facilitating contact with a parent when it is forbidden. SAP León, Section $2^{\text {nd }}, 117 / 2019,29.3 .2019$, refused granting contact because the emotional risk imposed on the children who were undergoing treatment in order to be able to have contact with their father as a result of violence and mistreatment during family life.

89 STS 666/2018, 21.11.2018. In the same sense, see the admissibility decision issued on 24.04.2019. 
contact with children decreases not because the holders of parental authority oppose to it, but as a result of the new family organisation after break-up' ${ }^{90}$ Awarding grandparent contact in this setting demands, therefore, to prove an adamant attitude of the parents against grandparents' involvement in the children's lives, not merely that visits have reduced or are now shorter or sporadic. Besides that, it is also pointed out rightfully that, 'while it is true that separation or divorce should not break the relationships that the minors previously entertain with other people, this does not mean that marriage or couple break-up is the best moment to create them ex novo'. ${ }^{91}$

\subsubsection{Death of one parent}

The death of one parent may provide more room to disregard whether a prior relationship with the children existed or not. It may well be that grandchildren are new-born and that the mother died during labour. The disruption caused by the sudden death of the parent justifies a higher degree of interference within the autonomy of the surviving parent. In such a case, the grandparents become the only people in this line of kinship; in other words, there is nobody else to keep this family connection alive.

This reasoning underlines the suggestion made by some scholars that grandparents enjoy the broadest contact arrangement in these cases. ${ }^{92}$ The rationale is that grandparents substitute for the absent parent. ${ }^{93}$

\subsubsection{Intact family}

Context is crucial to strike a fair balance between the interests at stake. From this standpoint, it cannot be ignored that the parents agree to limit or object to grandparents' contact. However, statutory contact rights are also enforceable in this case, and few seem to care about whether the interference with family autonomy is proportionate. ${ }^{94}$

Most authors claim that the test of the best interest of the child controls any case, including those involving intact families. However, we have seen how tricky this can be when this test is underperformed. In the case of an intact family-compared with the former instances of disruption by separation or death - the interests of the parents should not be relegated in favour of the interests of grandparents. Mere relatedness or kinship should be ineffectual..$^{95}$ On the other hand, where there has been a discontinuity of pre-existent meaningful relations, finding the best interest of the child requires a thorough analysis in which the parties shall explain why the relationship was discontinued and the benefits that opposing the

93 See M. Colás Escandón, 'El régimen de relaciones personales entre abuelos y nietos fijado judicialmente, con especial referencia a su extensión (A propósito de la STC, Sala 2. a , n. ${ }^{\circ}$ 138/2014, de 8 de septiembre)', Derecho privado y Constitución 2015 vol. 29, p. 133-185 at 169.

94 See Celdrán et al., p. 68, concluding that the assessment process in Spain is less dependent on parents' rights or on their attitude as legal carers of underage children than in other countries.

95 Anderson (p. 811) considers it necessary to clarify that 'blood ties do not always give rise to the closest relationships'. 
parents' decision entails for the children. Courts should grant contact with grandparents when evidence shows that this will avoid harm to children and provide them with benefits that counter the damage inevitably linked to the judicial action and the enforcement of the orders. ${ }^{96}$

Finally, it should be recalled that international human rights law seeks to protect existing interpersonal relationships. The obligation of States to preserve the family environment and maintaining relation ${ }^{97}$ refers to both parents and to 'any person holding custody rights, legal or customary primary caregivers, foster parents and persons with whom the child has a strong personal relationship' ${ }^{98}$ If children should be separated from the family, States shall ensure that they maintain linkages and relations with siblings, relatives and persons with whom the child has had strong personal relationships, unless this is contrary to the child's best interests. The Committee has stressed that 'the quality of the relationships and the need to retain them must be taken into consideration in decisions on the frequency and length of visits and other contact when a child is placed outside the family'. ${ }^{99}$

\subsection{The scope of grandparents' contact rights: fiction and reality}

The disconnection between the foundations of the current legal position of grandparents and the practical limits of the law is visible in the outcome of most litigated cases. In practice, courts award extended contact time only exceptionally, in connection with the death of one of the parents. If a prior close relationship of affection did exist, the arrangements are quite fair, but successful claims do not go beyond awarding contact once a week and in some special dates. In other cases, grandparents should perform their role by interacting with reluctant grandchildren for a limited time, often at inhospitable meeting points, and sometimes under the supervision of psychologists and social workers.

Scholars familiar with these conflicts suggest that orders must never be enforced by using coercion to bring unwilling grandchildren to their grandparents. ${ }^{100} \mathrm{How}^{-}$ ever, parents face the risks of being fined, ${ }^{101}$ having to pay damages ${ }^{102}$ or even being imprisoned if they fail to comply with the court orders. ${ }^{103}$ Since this result is highly undesirable for the minors involved in these cases, the enforcement of contact orders against reluctant parents has proven extremely difficult. Frustration and distrust of the law and the justice system is widespread among claimants.

96 Note that Celdrán et al., p. 69 conclude their in-depth analysis of a sample of psychosocial reports recalling that more data are needed to determine 'whether the open, grand-parent centred kind of recommendations identified in this study do indeed have real beneficial effects for families in conflict and, particularly, for grandchildren'.

97 See Arts. 9, 18 and 20 UNCRC.

98 Committee on the Rights of the Children, General comment no. 14 (2013), on the right of the child to have his or her best interests taken as a primary consideration (CRC/C/GC/14), no. 60. Emphasis added. Available at https://www.ohchr.org/en/hrbodies/crc/pages/crcindex.aspx.

99 Ibid., no. 65.

100 Colás Escandón, 2005, p. 78.

101 See SAP Barcelona, Section $18^{\text {th }}, 549 / 2018,05.10 .2018$.

102 Colás Escandón, 2011, p. 111-142.

103 See Colás Escandón, 2005, p. 136-137. 
On the other hand, grandparents' rights allegedly exist because of their reassuring role within the family. However, the use of legal procedure and its remedies inevitably triggers anger in the children's families as well as emotional instability. ${ }^{104}$ It seems evident that the stereotypical role of grandparents - providing stability, security, value transmission - cannot be performed in such a context of coercive enforcement of legal rights. It is also worrying that grandparents' rights are increasingly used against parents in intact families.

Some of the decisions commented upon in this section stress the need to try to rebuild personal relations in a natural and unforced way. They encourage the parties to solve the conflict by themselves, resorting to family mediation procedures or precisely designed family therapies. That is generally advisable for all family law disputes. It seems the only way that may provide a positive result to the parties in the subject matter of these pages.

\subsection{Conclusive remarks}

Evidence of the positive effects of having extended family relations are overwhelming. However, it does not mean that coerced contact with grandparents or extended family members by children whose parents have objected to the development of such relationships is in their welfare. As Herring put it, 'simply because a grandparent has a right does not mean that having contact is in the welfare of the child'. ${ }^{105}$ Spanish and Catalan legislation favour a one-size-fits-all approach based on presumptions derived from biological relatedness and abstract assertions about the welfare of the child. The legislative choice of a strong assumption that contact with grandparents is good and necessary, and the judicial disregard of the relevant context of each case, might have encouraged potentially harmful litigation. Current emphasis upon the need to consider the best interest of the child coincides with the higher proportion of cases involving children with whom grandparents have never had the opportunity to start a close relationship.

On the other hand, enhancing grandparents' legal rights has not prevented that many orders granting contact to grandparents who enjoyed a meaningful relationship with their grandchildren are left unenforced.

After almost twenty years since the reform was passed, rethinking the legal stance of grandparents' interest in contact with their grandchildren entails emphasizing that their welfare must be the only guide for decision-making. ${ }^{106}$ In the most recent rulings on the issue, both the Supreme Court and the Superior Court of Justice of Catalonia have stressed the need to assess the real benefits that the requested contact shall have for the grandchildren. Based on this premise, the examination of their best interests cannot be carried out regardless of the different scenarios in

104 Pointing to the adverse effects of judicialisation and the opportunity for family mediation, see R. Moliner Navarro, 'Protección legal de las relaciones abuelos-nietos en la jurisprudencia reciente', in: F. Blasco Gascó, M. Clemente Meoro, F.J. Orduña Moreno, L. Prats Albentosa \& R. Verdera Server (eds.), Estudios jurídicos en homenaje a Vicente Montés Penadés, vol. I, València: Tirant lo Blanch, 2011, p. 1661-1681.

105 J. Herring, Older People in Law and Society, Oxford: OUP, 2009, p. 254.

106 This is also a requirement that may be derived from case law issued by the ECtHR, in spite of the reasoning of certain recent decisions concerning Italy. In this sense see S. Kirsten, in this issue. 
which the grandparents' estrangement may have taken place, that is, whether or not the family in which the children live underwent some disruptive circumstance (such as divorce, separation or death).

\section{References}

\subsection{Legislation}

\section{Spanish}

Civil Code and Civil Procedure Act, as amended by Acts 42/2003, of 21st November (Boletín Oficial del Estado no. 280, 22.11.2003) and 26/2015, of $28^{\text {th }}$ July (BOE no. 180, 29.07.2015).

\section{Catalan}

Act 14/2010, of $27^{\text {th }}$ May, on the children's rights and opportunities (Diari official de la Generalitat de Catalunya no. 5641, 02.06.2010)

Act 25/2010, of 29 ${ }^{\text {th }}$ July, enacting the Second Book of the Catalan Civil Code, on persons and family (DOGC no. 5686, 05.08.2010)

\subsection{Case law}

\section{Spanish Constitutional Court [STC]}

STC 138/2014, $8^{\text {th }}$ September 2014

\section{Spanish Supreme Court (Civil chamber) [STS]}

STS 477/1996, 11.06.1996.

STS 17.09.1996.

STS 858/2002, 20.09.2002.

STS 632/2004, 28.06.2004.

STS 576/2009, 27.07.2009.

STS 320/2011, 12.05.2011.

STS 689/2011, 20.10.2011.

STS 359/2013, 24.05.2013.

STS 723/2013, 14.11.2013.

STS 167/2015, 18.03.2015.

STS 516/2015, 16.09.2015.

STS 551/2016, 20.09.2016.

STS 532/2018, 27.09.2018.

STS 666/2018, 21.11.2018.

STS 581/2019, 05.11.2019.

STS 638/2019, 25.11.2019.

Superior Court of Justice of Catalonia (Civil and Criminal chamber) [STSJC]

STSJC 9/2001, 19.02.2001.

STSJC 24/2014, 07.04.2014.

STSJC 1/2017, 12.01.2017.

STSJC 72/2018, 13.09.2018.

STSJC 63/2019, 23.10.2019 